Int. J. Dev. Biol. 56: 5-17

doi: $10.1387 / \mathrm{ijdb} .113441 \mathrm{mr}$

\title{
Evolutionary history of the Tricladida and the Platyhelminthes: an up-to-date phylogenetic and systematic account
}

\author{
MARTA RIUTORT**, ${ }^{*}$ MARTA ÁLVAREZ-PRESAS ${ }^{1}$, EVA LÁZARO ${ }^{1}$, EDUARD SOLÀ ${ }^{1}$ and JORDI PAPS ${ }^{2}$ \\ ${ }^{1}$ Institut de Recerca de la Biodiversitat (IRBio) i Departament de Genètica, Universitat de Barcelona, Spain and \\ ${ }^{2}$ Department of Zoology, University of Oxford, UK
}

\begin{abstract}
Within the free-living platyhelminths, the triclads, or planarians, are the best-known group, largely as a result of long-standing and intensive research on regeneration, pattern formation and Hox gene expression. However, the group's evolutionary history has been long debated, with controversies ranging from their phyletic structure and position within the Metazoa to the relationships among species within the Tricladida. Over the the last decade, with the advent of molecular phylogenies, some of these issues have begun to be resolved. Here, we present an upto-date summary of the main phylogenetic changes and novelties with some comments on their evolutionary implications. The phylum has been split into two groups, and the position of the main group (the Rhabdithophora and the Catenulida), close to the Annelida and the Mollusca within the Lophotrochozoa, is now clear. Their internal relationships, although not totally resolved, have been clarified. Tricladida systematics has also experienced a revolution since the implementation of molecular data. The terrestrial planarians have been demonstrated to have emerged from one of the freshwater families, giving a different view of their evolution and greatly altering their classification. The use of molecular data is also facilitating the identification of Tricladida species by DNA barcoding, allowing better knowledge of their distribution and genetic diversity. Finally, molecular phylogenetic and phylogeographical analyses, taking advantage of recent data, are beginning to give a clear picture of the recent history of the Dugesia and Schmidtea species in the Mediterranean.
\end{abstract}

KEY WORDS: Metazoa, molecular phylogeny, Tricladida, Platyhelminthes, systematic

\section{Introduction}

The Tricladida belong to the phylum Platyhelminthes, a phylum best known by their parasitic representatives and characterised by a general morphological simplicity. This simplicity has, from the very beginning, made the taxonomist's work difficult. Proof of this is the fact that the two first planarian genera, Planaria Müller, 1776 and Polycelis Ehrenberg, 1831, included many species not belonging to Tricladida (cf. Kenk 1974). The genus Planaria, which is now a valid genus of the Continenticola, was originally established by Müller (1776) to encompass all free-living lower worms. Thus, many species originally described as species of Planaria were later placed into other orders and suborders of Turbellaria or into the phylum Nemertina or Rhynchocoela. Similarly, the generic name Polycelis, introduced by Ehrenberg (1831), was originally applied by Diesing (1850) to all many-eyed turbellarians, which included terrestrial and polyclad turbellarians in addition to some freshwater planarians. The appearance of modern methodologies to define diagnostic, phylogenetic and systematic characters have gradually helped to partially solve this problem. Improved microscopy tools and staining procedures, the advent of electron microscopy, and more recently, the possibility of using monoclonal antibodies and confocal microscopy (unfortunately still in its infancy in Platyhelminthes studies) facilitate the discovery of defining features. At the same time, the use of molecular data to infer phylogenies has been crucial for understanding the origin and evolution of many Platyhelminthes features. Finally, molecular data are a key tool for understanding species' origins and demography, allowing the use of planarians as model organisms in the study of the origin and maintenance of biodiversity.

In this review we will use a top-down approach, beginning by revisiting the position of the phylum within the metazoans and re-

\footnotetext{
*Address correspondence to: Marta Riutort. Dpt. de Genètica, Facultat de Biologia, Universistat de Barcelona, Avda. Diagonal, 643, 08028 Barcelona, España. Tel: +34-93-403-5432. e-mail: mriutort@ub.edu - web: www.ub.edu/genetica/evo-devo/riutort.htm
} 
viewing the historical importance of flatworms in understanding the origins of bilaterians and their complexity. Finally, we will discuss recent advances in the phylogeography of particular groups and how these new data are of interest for both planarian scientists and biodiversity researchers.

\section{The Platyhelminthes}

\section{Morphology: from Gegenbaur to Ehlers}

The phylum Platyhelminthes includes more than 20,000 species and is the fourth-largest animal phylum after arthropods, molluscs and chordates (Ruppert et al., 2003). In addition, platyhelminths have played a key role in hypotheses regarding bauplan evolution, particularly the origin of bilateral symmetry, since the advent of evolutionary theory. They were originally named by German zoologist Karl Gegenbaur (1859), teacher and coworker of Ernst Haeckel, the same year that The Origin of Species was published. Their name is composed of the two Greek words platy, meaning "flat", and helminth meaning worm; thus, it is a direct translation of their vernacular name, "flatworms".

In Gegenbaur's time, the Animal Kingdom had already been divided into two major groups, the diploblastic animals and the triploblastic metazoans. The Diploblastica include sponges, cnidarians, ctenophores and placozoans; diploblasts have 2 embryonic layers (ectoderm and mesoderm) and have previously been referred to as the Radiata (due to their radial body symmetry) or the Coelenterata (although later on this term was restricted only to cnidarians and ctenophores). The Triploblastica, or Bilateria, include all other animals, which have a third developmental layer (mesoderm) and exhibit bilateral symmetry. The Platyhelminthes are bilaterians that are often described as having an austere architecture due to the absence of traits found in most bilaterians. Of particular note is the lack of coelom; however, other widespread characters are also missing in flatworms, such as the anus, mitosis in somatic cells and circulatory and respiratory systems. In contrast, many flatworms exhibit spiral embryonic cleavage, a type of development associated with several "complex" invertebrate phyla, such as annelids or molluscs. Because of this mix of simple and complex features, they have often been considered candidate representatives of the transition from diploblasts to triploblasts.

In the English translation of Gegenbaur's work (Gegenbaur et al., 1878), the platyhelminths were included within the metazoan division "Vermes" together with annelids, or "nemathelmintes" (nematodes and nematomorphs), among many other worms. Gegenbaur split Platyheminthes into four groups: the Turbellaria (Rhabdocoela and Dendrocoela, the latter including genera such as Planaria and Leptoplana), the Trematoda, the Cestoda and the Nemertina. Interestingly, the latter group corresponds to the contemporary phylum nemertines, which were considered platyhelminths at that time and were subsequently often linked to flatworms; this is because both of them were thought to be acoelomates, but more than 100 years later, the rhynchocoel of nemertines was proven to be a derived coelom (see a recent comprenhensive review on nemertines in Turbeville 2002). With regard to the coelom, Gegenbaur (1878) wrote the following: "In a large number of Vermes this perienteric space (Coelom) is either altogether absent, or only rudimentarily present. This is the case in most of the Platyhelminthes and Nemathelminthes." He later states, "In the land Planarians two cavities traversed by a reticulum of connective tissue extend along the body; they are largely broken up anteriorly. They are to be regarded as indications of a coelom of this kind". Despite including platyhelminthes in the Coelomata category, Gegenbaur's tree of the animals still placed flatworms (vermes) as the intermediate group representing the transition from diploblasts to triploblasts (Fig. 1A).

Haeckel's view of platyhelminths (or "Platodes", as he sometimes called them) is similar to Gegenbaur's in some respects. For instance, both use the same phylum subdivisions (Turbellaria, Trematoda and Cestoda) and include flatworms within "Vermes", along with the nemertines and onychophorans, or leeches (cf. Haeckel 1866). Regarding the coelom, Haeckel (vol II, p. 148, (1876)) differentiates himself from Gegenbaur by considering flatworms to be acoelomates: "For all the lower Worms which are comprised in the class of Flat-worms (Platyhelminthes), (the
A

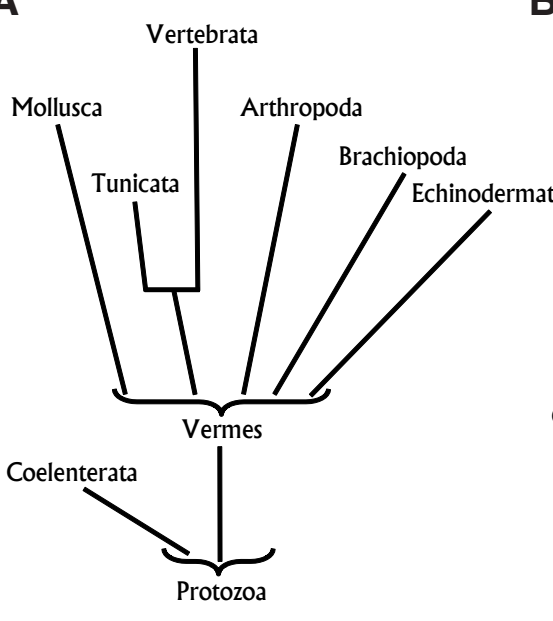

B HEMATARIA (Blood Animals)

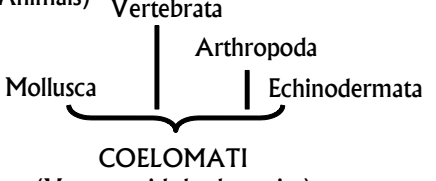

(Vermes with body-cavity)
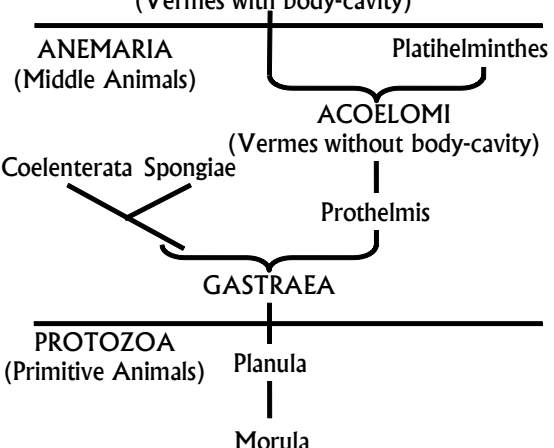

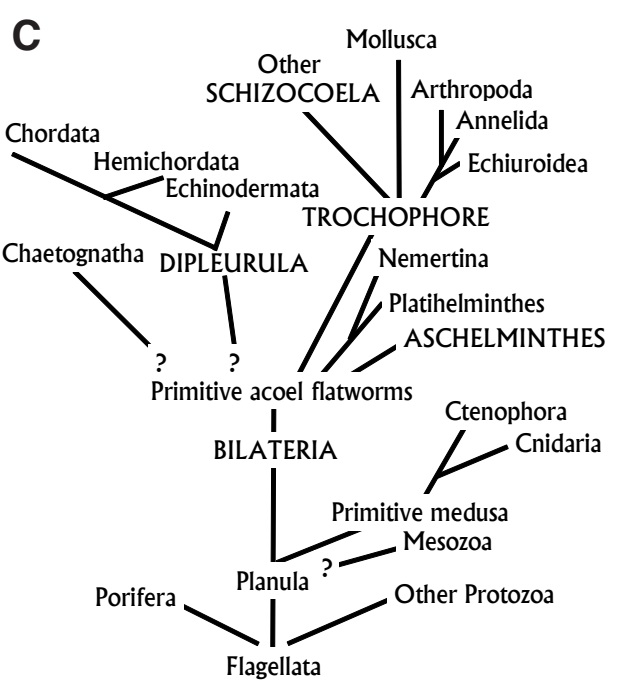

Fig. 1. Different views on the position of Platyhelminthes in the animal kingdom, based on morphology. (A) Gegenbaur (p.70, 1878). (B) Haeckel (Haeckel, 1874). (C) Hyman (1940). 
Gliding-worms, Sucker-worms, Tape-worms), differ very strikingly from other Worms, in the fact that they possess neither blood nor body-cavity (no coelome); they are, therefore, called Acoelomi (..) But all other Worms (like the four higher tribes of animals) possess a genuine body-cavity and a vascular system connected with it, which is filled with blood; hence we class them together as Coelomati." Based on his famous Gastraea theory, Haeckel places flatworms in a critical position in the animal tree, deriving an ancestral flatworm-like animal from the ancestral gastraea (see Prothelmis, also called Archelminthes, in Fig. $1 \mathrm{~B}$ ): "The main division of Bloodless Worms (Acoelomi) contains, according to our phylogenetic views, besides the still living Flat-worms, the unknown and extinct primary forms of the whole tribe of Worms, which we shall call the Primaeval Worms (Archelminthes) (..) that may be directly derived from the Gastrea.".

Haeckel was not the only pre-cladistic zoologist to use life stages in his phylogenetic hypotheses. Many sources attribute the division of bilaterians into three groups based on presence, absence or type of body cavity to American zoologist Henrietta Libbie Hyman: acoelomates (no cavity), pseudocoelomates (cavity derived from the early blastocoel) and coelomates (cavity appears later in development and is limited by an epithelium). Moreover, Hyman is often credited with proposing acoelomates as the first evolutionary offshoot from bilaterians, followed by pseudocoelomates as a sister group to coelomates, which supports a trend of increasing complexity in evolution. In fact, Hyman used this tripartite division of bilaterians to structure her magnum opus, The Invertebrates (Hyman 1940), but this organisation was more pedagogical than grounded in her ideas on animal evolution (Garey 2002). Instead, her views on metazoan phylogenetics were mostly driven by larval stages, following the planuloid-acoeloid hypothesis of Von Graff (Graff 1882). She derived both the Radiata (cnidarians and ctenophorans) and the Bilateria from a planula-like organism, with bilaterians originating from an acoel flatworm that gave rise to the Protostomia and the Deuterostomia (Fig. 1C). Hyman, who was very fond of the Turbellaria, disliked the term "Vermes" (Hyman 1940, p32): "[the group Vermes] can only be defined in general and mostly negative terms (i.e., as worm-like animals without skeleton or jointed appendages) and which unites animals of remote and indeterminable relationship while separating groups admittedly closely allied (..) is futile and confusing". She recognised the acoelomate status of platyhelminthes and separated them from nemertines due to the presence of an anus in the latter.

A prediction of the above hypotheses is that the flatworm bodyplan should be simple and ancestral to bilaterians. This point of view is in conflict with later proposals, primarily based on cladistic principles, which supported the idea of platyhelminths as derived protostomates whose bauplan has been secondarily simplified. Cladistic studies proliferated in the second half of the past century, but far from resolving the question on animal evolution, the new unified criteria for inferring phylogenetic trees produced a myriad of trees and did not resolve outstanding questions (a review of them can be read in Valentine 2004). Those years saw a parade of possible sister groups to Platyhelminthes: the Gnathostomulida, the Nemertea, the Gnathifera, or even the annelids and molluscs, based on their shared spiral cleavage. This instability was probably caused by the fact that most of the traits used in those studies are now recognised as symplesiomorphies or homoplasies (Baguñà, Riutort 2004).
At the same time, the monophyly of the group was under debate. Due to the lack of synapomorphies, the platyhelminths were divided in three groups: the Acoelomorpha (Acoela and Nemertodermatida), the Catenulida and the Rhabditophora (Smith et al., 1986). Later, molecular data confirmed the lack of monophyly, suggesting acoelomorphs as the first offshoot of the bilaterian stem (Carranza et al., 1997; Ruiz-Trillo et al., 1999), whereas the Rhabditophora and the Catenulida constituted a monophyletic group. During those years, the Platyhelminthes also acquired a new member: the newly described Xenoturbella. Its status as flatworm, however, was controversial (see a review in Nielsen 2010). Molecular data first rejected its classification as a flatworm, but recent analyses have linked Xenoturbella to the acoelomorphs. While the wandering of acoelomorphs and xenoturbellids across the evolutionary tree of the animal kingdom is an interesting story, and most likely one far from ending, it is outside of the scope of this paper; therefore, from here onwards, we will use the term Platyhelminthes to refer to the Catenulida and the Rhabditophora (Baguñà, Riutort 2004). As exemplified by acoelomorphs and xenoturbellids, the uncertainties about the position of platyhelminths raised by morphology were replaced by new ones as the field of Systematics entered the molecular age.

\section{Molecules: from one to many genes}

The history of metazoan molecular phylogeny can be divided into three main stages: the beginning, using $18 \mathrm{~S}$ ribosomal RNA gene (18S) sequence, followed by a short multigenic period and the current phylogenomic era. The pioneering work of Field and collaborators (1988) joined metazoan phylogenetics and molecular biology through $18 \mathrm{~S}$ sequencing. The newly born field would encounter hurdles during its first years, primarily due to a low sampling of phyla and problems such as Long Branch Attraction (LBA), among others (Abouheif et al., 1998). However, as the years passed, the sampling coverage was increased to a great extent, and innovative methods and evolutionary models were developed to deal with systematic and stochastic errors. In the second half of the 1990s, two papers transformed our view of metazoan evolution, providing what was called the New Animal Phylogeny (see a review in Halanych 2004). In this new evolutionary tree of the animals, the Bilateria were divided into three superclades: the Lophotrochozoa (comprising platyhelminths, lophophorates, annelids and molluscs, among many other phyla), the Ecdysozoa (embracing arthropods, nematodes and other traditional pseucoelomate worms) and the Deuterostomia.

The Platyhelminths would enter the molecular age represented by a single $18 \mathrm{~S}$ sequence from the tricladid Girardia tigrina (then Dugesia tigrina ) (Field et al., 1988). This first flatworm sequence was placed at the first bilaterian split, a position matching the hypotheses posed by Hyman and her precursors. The first broad phylogeny for the platyhelminths using $18 \mathrm{~S}$ sequences was described in the study of Carranza and collaborators (Carranza et al., 1997), which indicated the separation of acoelomorphs-and, surprisingly, the catenulids as well-from the rest of the phylum; the main novelty in this study was that for the first time, the bulk of Platyhelminthes were placed within the Protostomates. Later works would recover the catenulids as a sister group to rhabditophorans within the lophotrochozoans and confirm the divorce of acoelomorphs and the platyhelminths (Jondelius et al., 2002; Ruiz-Trillo et al., 1999). 
The second age of molecular phylogenetics would add more markers to the standard $18 \mathrm{~S}$ analysis, first the $28 \mathrm{~S}$ sequence (Mallatt et al., 2010; Mallatt, Winchell 2002; Medina et al., 2001; Paps et al., 2009b; Telford et al., 2003) and later protein coding genes, analysed alone or concatenated. However, the combination of the two ribosomal genes did not overcome the inference artefacts of 18S alone (Mallatt et al., 2010; Paps et al., 2009b), and the signal from protein coding genes when analysed individually lacked statistical support, with two notable exceptions: the alpha subunit of the sodium-potassium ATPase (Anderson et al., 2004) and the myosin heavy chain type II (Ruiz-Trillo et al., 2002). Finally, before systematics entered the high-throughput era, a handful of works used concatenated alignments (from 7 to 23 genes) for a significant number of phyla (Bourlat et al., 2008; Paps et al., 2009a; Sperling et al., 2009). All these works placed platyhelminths within the lophotrochozoans once again, although they were variably positioned and had varying degrees of support.

The access to sequencing facilities and the decreasing cost of high-throughput sequencing has made a great quantity of partial genomic data available. This has resulted in new challenges and approaches to deal with the vast amount of information produced by these methods. Nevertheless, it has been shown that the perils of phylogenetic inference (i.e. LBA) are not completely removed by the use of more characters. Phylogenomic studies of metazoans have culminated in two major sequencing efforts, represented by the studies of Dunn and collaborators (Dunn et al., 2008) and $\mathrm{He}$ jnol and collaborators (2009). While both studies analysed a large number of markers (150 and 1,500 genes, respectively), some of

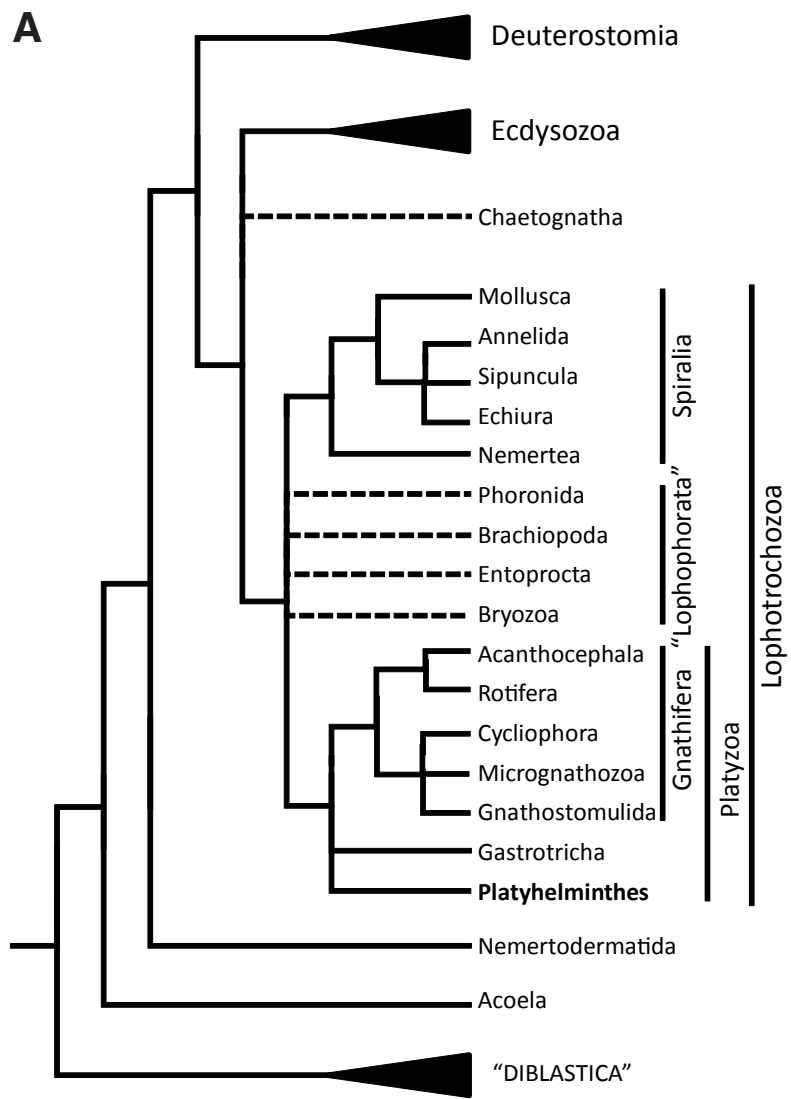

the inter-phyla relationships are weakly supported. Re-analysis of this data with filtered markers and alternative evolutionary models obtained stronger statistical support (Philippe et al., 2011). Again, all analyses place the platyhelminths among the lophotrochozoans, but their position within this group and, hence their evolutionary history, remains elusive.

\section{Platyhelminthes in the 21st Century: simple or simplified?}

The position of the Platyhelminthes within lophotrochozoans is vital for understanding the origins of their body plan in the context of animal evolution. Despite the lack of resolution of most molecular trees, the position of the platyhelminths can be summarised in two possible scenarios (Fig. 2). The first is the Platyzoa hypothesis (Giribet et al., 2000), which suggests that the platyhelminths form a group (the Platyzoa) together with the gastrotrichs and the Gnathifera (rotifers, gnathostomulans and cycliophorans, among others). The platyzoans would be defined as ciliated, non-segmented acoelomates or pseudocoelomates that lack a vascular system and have a straight gut (when present), with or without an anus (CavalierSmith 1998). This platyzoan clade would be a sister group to the Spiralia, the coelomated lophotrochozoans with spiral cleavage and trochophora larva (i.e., annelids, molluscs, nemertines). The second scenario would place the Platyhelminthes alone as a sister group to the Spiralia, deeply nested within the lophotrochozoans and splitting off after an extensive ladder of many platyzoan and lophophorate phyla (Paps et al., 2009b; 2009a).

The Platyzoa hypothesis divides the lophotrochozoans into two branches, one with all of the "simple" phyla together and the other

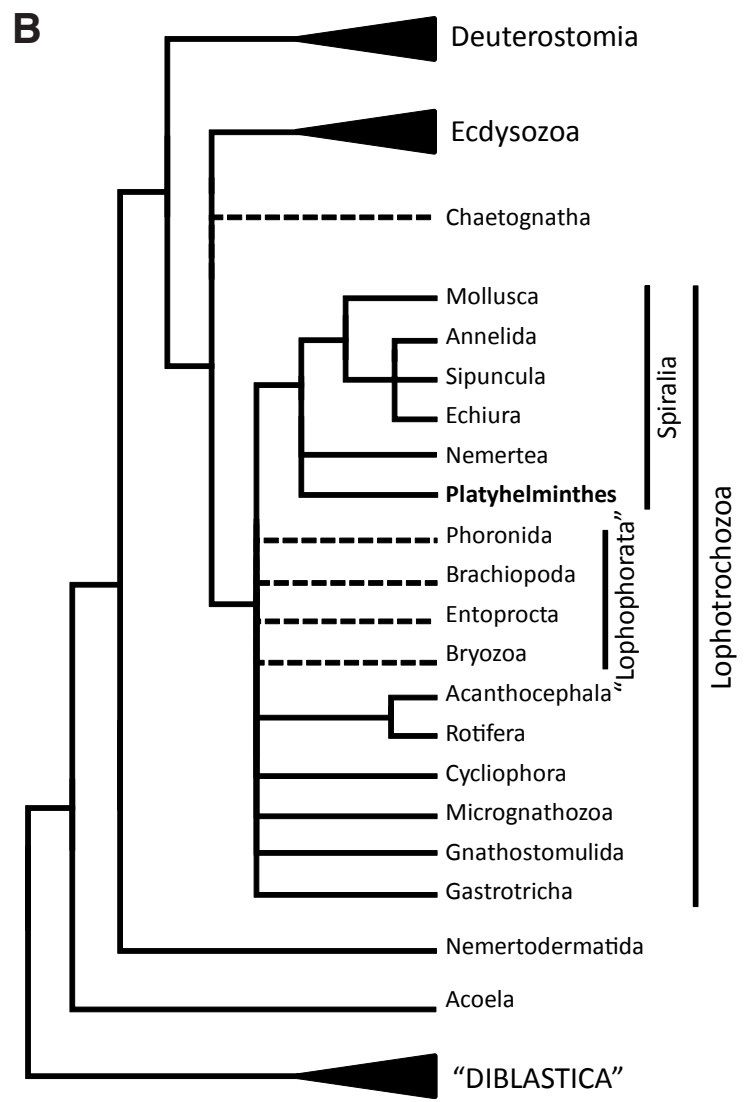

Fig. 2. The positions of Platyhelminthes based on molecular data. (A) Platyzoa hypothesis. (B) The Platyhelminths sister group to Spiralia nested within the Lophotrochozoa. 
A

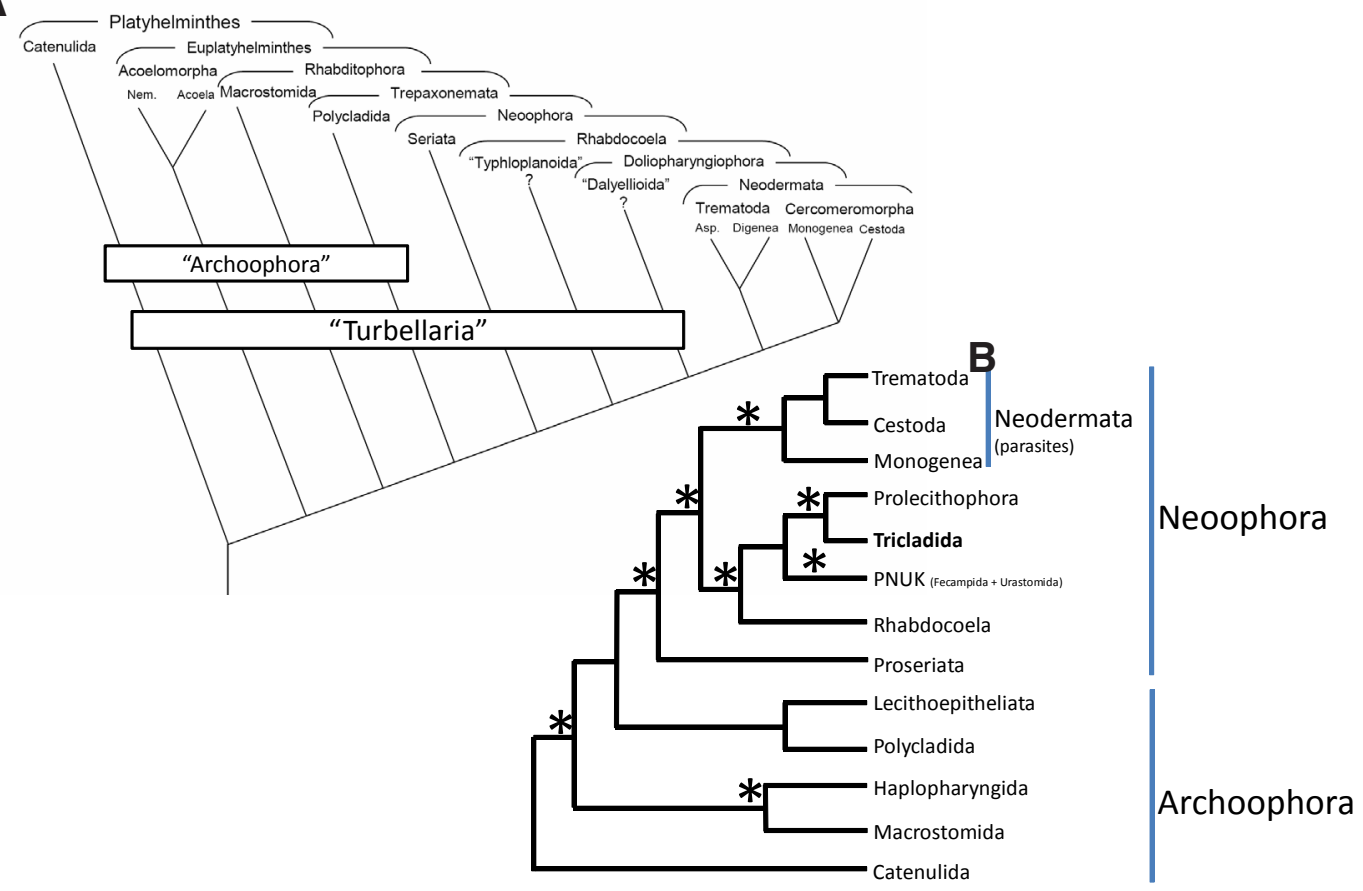

Fig. 3. Internal relationships of the Platyhelminthes. (A) Ehlers (1985) scheme. (B) Tree summarising the relationships obtained in different studies based on ribosomal genes. * Strongly supported nodes.

leading to more "complex" animals; this scenario leaves open the question of the last common ancestor of the Lophotrochozoa, as it could either be a complex animal that underwent simplification in the platyzoan lineage or the opposite. Therefore, without knowing the ancestral level of complexity, we cannot conclude whether flatworms are simple or simplified. The second hypothesis, with flatworms branching deep inside relatively more complex lophotrochozoans (i.e. lophophorates) and next to the Spiralia, points to a simplification process of the phylum; however, it is still possible that flatworms were originally simple and there was a parallel increase of complexity in the groups surrounding them.

\section{Internal relationships within the Platyhelminthes}

Historically, the Platyhelminthes were divided in three classes, the free-living class "Turbellaria" and two parasitic classes, the Cestoda and the Trematoda (since further divided into three Classes collectively named Neodermata: the Trematoda, the Cestoda, and the Monogenea) (Gegenbaur 1859; Haeckel 1866; Hyman 1951). The class Turbellaria was subsequently divided into a series of orders ( 11, depending on the authors). Comprehensive morphological analyses, however, showed that the parasitic groups evolved from free-living platyhelminths and that the "Turbellaria" thus constituted a paraphyletic group (Ehlers 1985), a situation indicated by the quotes around the name (Fig. 3). The earliest rigorous morphological study of the group is by Karling (1974), while Ehlers (1985) (Fig. $3 \mathrm{~A})$ conducted the first cladistic analysis, which has defined the structure of the Platyhelminthes' internal relationships for a long time. However, later morphological studies have refined some groupings (Smith et al., 1986, Haszprunar 1996a,b; and Littlewood et al., 1999b, this last including molecular data). These studies agreed in most regions of the tree, recognising three monophy- letic groups within the flatworms: the Acoelomorpha (Acoela and Nemertodermatida), the Catenulida, and the Rhabditophora (the largest group, comprising approximately eight free-living orders and the three classes of parasites) (Table 1). Within the Rhabditophora, the turbellarian orders were divided into the archoophorans (with homocellular female gonads, entolecithal eggs, and cannonical spiral cleavage) and the neoophorans (with heterocellular female gonads, i.e., with separate germaria and yolk glands, and ectolecithal embryos), the archoophorans being paraphyletic (Fig. 3). However, doubts about the relationships among the three major

TABLE 1

\section{MAIN GROUPS AND ORDERS CLASSICALY CONSIDERED WITHIN THE PLATYHELMINTHES}

Class "Turbellaria"
Acoelomorpha
Order Acoela
Order Nemertodermatida
Order Catenulida
Rhabditophora
Order Macrostomida
Order Haplopharyngida
Order Lecytoepiteliata
Order Polycladida
Order Proseriata
Order Rhabdocoela
Order Tricladida
Order Prolecitophora
Class Trematoda
$\begin{gathered}\text { Class Cestoda } \\ \text { Class Monogenea }\end{gathered}$

See Figure 3 for their phylogenetic relationships; some of them do not have a taxonomic rank. As of today, Acoelomorpha (Acoela and Nemertodermatida) do not belong to the Platyhelminthes. 
groups (the Acoelomorpha, the Catenulida and the Rhabditophora) and even the monophyly of the whole phylum persisted (Smith et al., 1986). As explained above, the use of molecular data demonstrated the phylum to be polyphyletic, and thus, their description to be in need of reconsideration. The phylum was therefore redefined as a monophyletic group consisting of the Catenulida and the Rhabditophora (Baguñà, Riutort 2004) the latter including all free-living orders (except Catenulida) and the three parasitic groups (Cestoda, Trematoda and Monogenea). This organisation poses a taxonomic (nomenclatural) problem for the group, as most books still give a class rank to the three parasitic groups, as well as to the disused "Turbellaria", while their free-living sister clades have the rank of order. This results in a strange taxonomical arrangement and points to the need for a revision of the taxonomy of the whole group to reflect our current understanding of their relationships.

Molecular data have also been used to assess the relationships among orders and classes within the phylum, and these studies have been extensively reviewed in Littlewood and Olson (2001) and Baguñà and Riutort (2004). As in other cases, the first works suffered from poor sampling and inadequate knowledge of the limitations of molecular phylogenetic inference, which led to incorrect conclusions in many cases. The development of more sophisticated analytical methods and more thorough sampling has produced better-resolved phylogenies. Unfortunately, most of these works were led by researchers with interests in particular groups that, together with the difficulty in sampling most orders, has led to biased representations of orders within the phylogenies. Moreover, interest in solving the complete flatworm phylogeny disappeared as soon as these workers were able to establish the closest relative to their groups of interest, leaving the tree still full of uncertainties (Fig. 3B). All of these projects were based on ribosomal genes, and no attempt has been made to use multiple markers. Perhaps the reduced cost and increased sensitivity of new high-throughput methodologies, which enable whole-genome sequencing from individual small organisms, will encourage researchers to fully resolve the Platyhelminthes tree. Despite this pessimistic scenario, a general picture of the main relationships has emerged based on multiple molecular studies (Fig. 3B) and can be summarised as follows:

1. The Catenulida are the most basal group within the Platyhelminthes (sensu (Baguñà, Riutort 2004).

2. Within the Rhabditophora, the orders Macrostomida, Haplopharyngida, Polycladida and Lecithoepitheliata are basal groups with uncertain relationships among them but a clear sistergroup relationship to the rest of the Rhabditophora; this gives support to the derived status of the neoophoran gonad and, hence, to the monophyly of the group.

3. Within the Neoophora, the order Seriata, which included the infraorders Tricladida and Proseriata, is eliminated. The Proseriata are now basal within the Neoophora (also pointed out by Rohde (1990) on morphological grounds), whereas the Tricladida have moved to a more derived position within the tree.

4. In all molecular studies, the sister group of the Tricladida is the Prolecitophora, another group that Ehlers situated basally within the Neoophora. This tight molecular relationship was never suggested at the morphological level and seems not to have any morphological synapomorphy to support it.

5. There is no doubt about the monophyly of the Neodermata (Trematoda, Cestoda, Monogenea), which implies that obligate parasitism, present in all its members, evolved only once. However, a few other species within the free-living lineages are also parasitic or commensal (some groups within the Fecampiida and Urastomidae). Many of these groups share features similar to those present in the Neodermata, such as sperm morphology and a considerable reduction of internal organs. This led several authors to propose that the sister group of the Neodermata would consist of one or some combination of these groups, assuming a relatively recent origin for the Neodermata. However, molecular analyses contradicted these hypotheses.

6 . The parasitic and commensal species belonging to the Fecampida and the Urastomidae (Piscinquilinus, Notentera, Urastoma and Kronborgia (PNUK) (Littlewood et al., 1999a, b) are grouped in a cluster with the Rhabdocoela, together forming the sister group of the Tricladida + the Prolecithophora clade. This situation leaves the Neodermata with no close "turbellarian" sistergroup and contradicts its Rhabdocoela membership, implying a more ancient origin than that proposed with morphological data and that some of the characters shared by the "turbellarian" parasites and the Neodermata evolved convergently, probably as an adaptation to their parasitic life history.

7. The clade including the Tricladida + the Prolecitophora, the Rhabdocoela and PNUK is well supported by molecular data, but the internal relationships among them are not well resolved. Noren and Jondelius (Noren, Jondelius 2002) found weak support for a clade constituted by the Tricladida + the Prolecitophora and PNUK

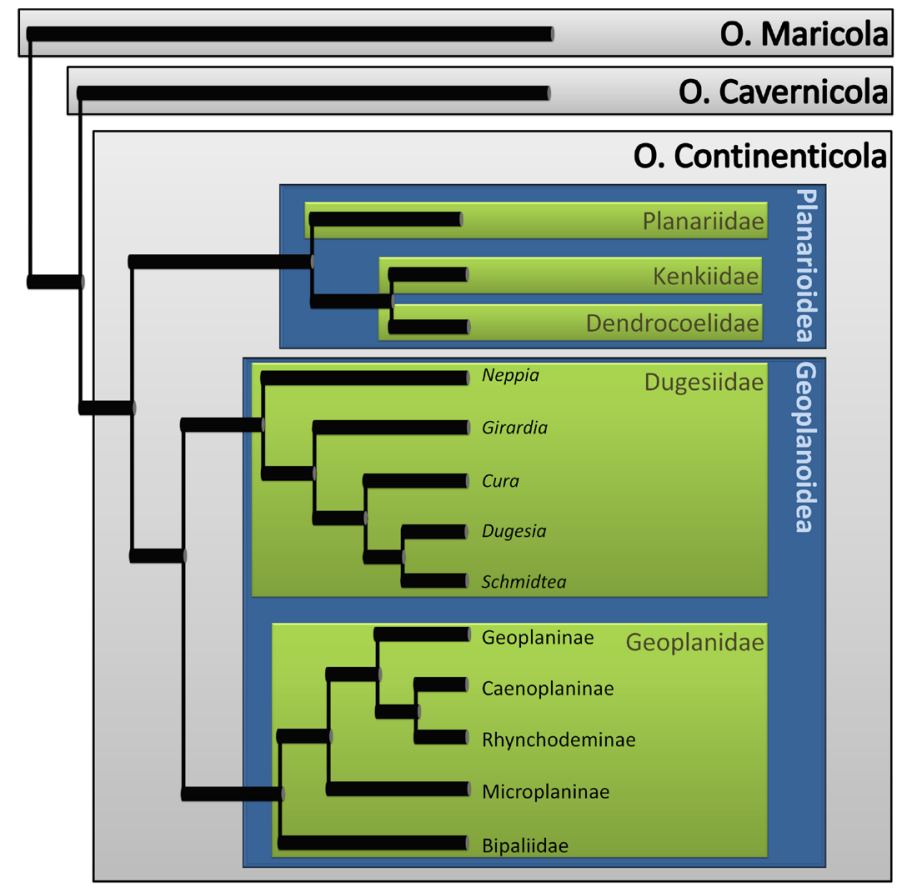

Fig. 4. Phylogenetic tree summarising the current understanding of the internal relationships of the Tricladida. The tree is primarily based on molecular data, although the Kenkidae and Cavernicola relationship is based exclusively on morphology. The Dugesidae genera Spathula, Romankenkius and Reynoldsonia have not been included for the sake of clarity (they would be sister group to Microplaninae within Geoplanidae, see text); the genera Bopsula, Eviella and Weissius have not been included because they have never been subjected to molecular analyses, and there is no clear position for them on morphological grounds. 
(PNUK was named Fecampida in that work); they proposed a name for this clade (the Adiaphanida) based on the only identified feature shared by the three groups: most of the species in this clade have more or less opaque bodies. However, the lack of support for the group discourages the use of this name.

Phylogenetic knowledge below the order level is even more fragmentary, resulting in complex taxonomies. As discussed above, the morphological simplicity of the group makes systematic assessment difficult. Hopefully, future application of molecular techniques at this level will help to clarify the relationships and taxonomy.

\section{The Tricladida (Lang, 1884)}

Triclads occupy a derived position within the Platyhelminthes tree, with a clear sister group relationship to the Prolecitophora and close affinity to the Rhadocoela and the group of parasitic "Turbellaria" PNUK. However, these relationships do not reveal any ancestral characteristics because the group does not seem to share any morphological synapomorphies. The Triclads are characterised by a well-defined digestive cavity, consisting of a single anterior gut that splits to produce two posterior branches (which gives the name to the group). They also share other synapomorphies, such as the crossing over of pharynx muscles, embryological features, the cerebral position of female gonads, the serial arrangement of many nephridiopores and a marginal adhesive zone. Within them we can find the largest free-living rhabditophorans: some terrestrial planarians that can reach 1 meter in length and one described abyssal freshwater planarian from lake Baikal that reaches 30-40 $\mathrm{cm}$ in length and $10 \mathrm{~cm}$ in width.

Hallez (1894) divided the Tricladida into three ecological groups: the Paludicola (freshwater planarians), the Terricola (land planarians), and the Maricola (marine planarians). This division received a taxonomic rank (that varied between sub- and infraorder) and has been used since by all taxonomists, though a doubt was cast on the phylogenetic validity of these ecological groupings. Sluys (1990) proposed a fourth clade, the Cavernicola, grouping five species (belonging to four genera); four of them had been formerly assigned to the Maricola but with apparent closer affinities to the Paludicola. The systematic and phylogenetic relationships of these groups have been discussed on the basis of morphological and ultrastructural characters by Ball (1981), Sopott-Ehlers (1985), and Sluys (1989a). Within the triclads, Ball followed the division of the Tricladida proposed by Steinböck (1925) and considered the Terricola to be the sister group of a clade consisting of the Maricola and the Paludicola (Haploneura). While the Terricola were well defined by their complex diploneural nervous system, the Haploneura did not show clear synapomorphies. Moreover, no synapomorphies were found for the Maricola, but two presumed synapomorphies defined the Paludicola: their reduced precerebral diverticula and the position of the copulatory bursa anterior to the male copulatory apparatus (probursal condition). Sluys (1989a) presented a new phylogenetic scheme based on a reassessment of morphological characters. New traits were found to support the monophyly of the Terricola, the Maricola and the Paludicola, as well as to suggest a closer relationship between the Terricola and the Paludicola clades, changing the evolutionary scheme proposed by Ball.

A radically different view of the internal relationships of the Tricladida emerged from phylogenetic studies based on sequences of $18 \mathrm{~S}$ ribosomal genes, showing the Terricola to be a sister group to the freshwater family Dugesiidae; this scenario was confirmed by the finding of a molecular synapomorphy, the presence of a shared $18 S$ gene duplication (Carranza et al., 1998). Therefore, the Paludicola emerged as paraphyletic because their previous sister group Terricola was now nested within them. The taxa Terricola and Paludicola became invalid and were replaced by a new taxon, the Continenticola (Carranza et al., 1998). Later molecular studies (Baguñà et al., 2001; Álvarez-Presas et al., 2008) lent further support to the clustering together of the Terricola and the Dugesiidae and of the Terricola and the Dugesiidae to their sister-group, the Planariidae + the Dendrocoelidae (Planarioidea) (Fig. 4).

Regarding taxonomic ranks, the Tricladida were originally a suborder within the order Seriata (Ehlers 1985), and the groups within ithad the rank of infraorder (Maricola, Paludicola, Cavernicola and Terricola). In the new classification of the group, taking into account the new understanding of their phylogenetic relationships (Sluys et al., 2009), the Tricladida have order rank and include three suborders, the Maricola, the Cavernicola and the Continenticola (Fig. 4, Table 2).

The relationships within the Tricladida suborders have received uneven attention. Based on morphological characters, they have been considered in some detail within the Maricola (Sluys 1989b), the Cavernicola (Sluys 1990) and the former Paludicola (Ball 1974; De Vries, Sluys 1991; Sluys 1989a) but not the former Terricola. On the other hand, extensive molecular analyses have been performed on the Continenticola (including both former Paludicola and Terricola), but only a very preliminary study has been done for the Maricola, while the Cavernicola have not been studied.

\section{TABLE 2}

\section{NEW CLASSIFICATION OF THE TRICLADIDA (LANG, 1884)}

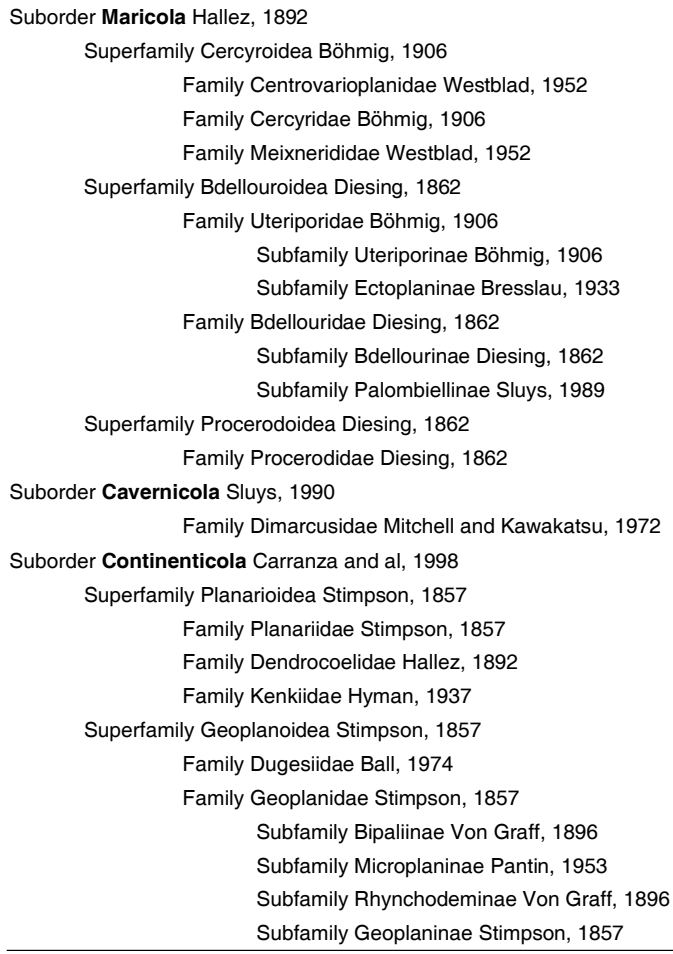

Sluys et al., 2009 
At present, the Maricola are divided into three superfamilies and are subdivided into six families (Table 2), although the number and groupings of the families have varied historically (see Sluys 1989b for a detailed account). In his monograph, Sluys (1989b) proposed the first and only cladistic phylogeny for the Maricola. He found synapomorphies giving support to the monophyly of the superfamilies, except for the family Meixneridae (now included within the Cercyroidea), which has uncertain relationships. The Cercyroidea are proposed to be the most basal maricolans, sister to a clade constituted by the Procerodoidea and the Bdellouroidea. The only molecular study (Charbagi-Barbirou et al., 2011) finds, with strong support, the family Procerodidae (superfamily Procerodoidea) to be basal to the rest of the families, while the Cercyroidea occupy a derived position in the tree, contradicting the morphological data. With regard to the remaining relationships, the molecular tree recovers a paraphyletic Bdellouroidea (because it includes the Cercyroidea), within which the monophyly of its two component families (Uteriporidae and Bdellouridae) is not recovered. In fact, there are no morphological synapomorphies giving support to the monophyly of the Uterioporidae, but in the case of the family Bdellouridae, the molecular result is strongly contradicted by morphological data. The systematics of this group remains open and in need of extensive morphological and molecular studies.

Sluys (1990) defined the clade Cavernicola formed by five species (grouped into a single family, the Dimarcusidae) based on three morphological features related to the reproductive apparatus. Concerning their phyletic position within the Tricladida, he found many features inconsistent with its belonging to the Maricola (as initially proposed for four of the five species). Sluys (1990) suggested a closer relationship to the Paludicola than to the Maricola, due to the fact that the Cavernicola share one of the three apomorphies of freshwater triclads. However, at that time, the Terricola and the Paludicola were still considered to be independent sister groups; under the current Continenticola hypothesis, Sluys' proposal of a closer affinity of the Cavernicola to freshwater planarians could point to the inclusion of the Cavernicola within continenticolans. Unfortunately there is no easy way to obtain representatives of this group; hence, the final answer to their systematic status will have to wait.

\section{Continenticola}

This suborder combines the former Paludicola and Terricola; hence, to follow its history, we need to revise both groups. Within the Paludicola, Hallez (1894), in his revision of the group, recognised nine genera divided in two families, the Planaridae Stimpson, 1857 (now Planariidae) and the Dendrocoelidae Hallez, 1894, the second differing from the former in the possession of anterior adhesive organs. The first attempt to present a "natural" checklist of the Paludicola was made by Kenk (1930), who arranged those species that were sufficiently well investigated into two families, the Planariidae and the Dendrocoelidae, defined by the arrangement of the inner muscle layers of the pharynx. In the Planariidae, the circular and longitudinal muscles of the inner muscle zone of the pharynx form two separate layers, whereas in the Dencrocoelidae, the circular and longitudinal muscle fibres are intermingled. These internal characters confirmed Hallez's original division based exclusively on external features. The distribution of the genera was the same in both schemes, although many more genera had been described by the time Kenk proposed his revision. In 1974 Kenk produced an index of genera and species of freshwater planarians of the world, which was mainly a nomenclatural account in which he clarified the synonymies of many species and the multiple cases of organisms belonging to other orders of Platyhelminthes - or even to other phyla - that had been included in the Tricladida genera. The same year, Ball (1974) established the family Dugesiidae by extracting several genera from within the Planariidae, defining the new family by its unique eye structure, a multicellular pigment cup with numerous light receptive cells. He also proposed that the new family was the sister group of a clade composed of the other two (Planariidae and Dendrocoelidae) families sharing a common oviduct entering the atrium. Hyman (1937) had previously established a new family that included 3 genera of cave planarians, the Kenkiidae, and later findings included more genera within this family. Nonetheless, several authors did not accept their validity, and in the 1960s, their elimination was proposed (de Beauchamp 1961; Mitchell 1968). Hence, later analyses, such as those of Ball described above, considered them to be a subfamily (Kenkiinae) within the Planariidae. Finally, Kenk ((1975)) proposed that the subfamily Kenkiinae should be upgraded to the family level (Kenkiidae), and a recent detailed morphological study (Sluys, Kawakatsu 2006) showed that this family is more closely related to the Dendrocoelidae than to the Planariidae.

The Terricola were taxonomically divided into three families (Geoplanidae Stimpson, 1857, Bipaliidae Graff, 1896, and Rhynchodemidae Graff, 1896) for which no cladistic study has been undertaken. The Continenticola scenario raised by molecular data has resulted in a major taxonomic reorganisation for the Terricola. As a consequence of their sistergroup relationship to Dugesiidae, terrestrial planarians have seen their rank downgraded to the family level; hence, all its previous families became subfamilies (Table 2 ), and some subfamilies became tribes. The name selected for the family including all terrestrial planarians is Geoplanidae, as this was the older family designation for the terrestrial planarians (Stimpson, 1857), originally housing all of them. The families Dugesiidae and Geoplanidae have been taxonomically grouped into the Superfamily Geoplanoidea at an equivalent rank to the superfamily Planarioidea (the Planaridae + the Dendrocoelidae).

Again, there is a large asymmetry in the systematic and phylogenetic study of this group. Of the two superfamilies included within the Continenticola, the Planarioidea and the Geoplanoidea, the first has received little attention from a systematic point of view. Within it, only the Dendrocoelidae have been the object of a phylogenetic study based on morphological data (Sluys, Kawakatsu 2006).

\section{Planarioidea (Stimpson, 1857)}

The Planarioidea, including the families Planariidae, Dendrocoelidae and Kenkiidae, exhibit a Holarctic distribution. The Planariidae were the first paludicolan family established and included all genera known at that time. Sluys and Kawakatsu (2006) considered the Kenkiidae and the Dendrocoelidae to share the adhesive organ (previously interpreted as a convergent character, (de Beauchamp 1961; Mitchell 1968)), constituting a likely synapomorphy for their grouping. These workers also found a series of morphological characters that allowed them to define monophyletic groups within the family Dendrocoelidae. Despite inferring a phylogeny for these monophyletic groups, they do not provide any taxonomic rank for them. It is noteworthy that the Dendrocoelidae have undergone 
an impressive radiation in Lake Baikal, from where more than 13 endemic genera have been described.

\section{Geoplanoidea (Stimpson, 1857)}

This superfamily was originally proposed by Stimpson (1857) to include the two families in which he divided the terrestrial planarians, the Geoplanidae and the Polycladidae (this latter group was later abandoned). Today, this superfamily houses all the freshwater planarians from the family Dugesiidae as well as all the terrestrial planarians (family Geoplanidae) (Sluys et al., 2009). The Geoplanoidea are supported by molecular trees based on the two ribosomal genes and mitochondrial cytochrome oxidase I (COI) (Álvarez-Presas et al., 2008), in addition to the presence of a ribosomal gene cluster duplication. In their initial proposal, Carranza and collaborators (1998) suggested the complex eye found in the Dugesidae and in terrestrial planarians as a possible morphological synapomorphy for the group. In fact, Ball (1981) had already considered the similar eye structure in the dugesiids and the terrestrial planarians as a weakness in his phylogenetic proposals. However, recent studies (Sluys, Kawakatsu 2006) have shown eyes with a similar structure to be present also in the dendrocoelids, thus casting doubt on the validity of this character as a defining feature for the Geoplanoidea. Nonetheless, Falleni and collaborators (2009) have found an ultrastructural character related to the morphology of the female gonad that can be considered as a synapomorphy for the group.

The most recent molecular study of the superfamily (ÁlvarezPresas et al., 2008) showed that a single transition occurred from freshwater to the terrestrial habitat (from a common ancestor with the Dugesiidae). The origin of this group is probably more than 100 million years old (Carranza et al., 1999), and it was likely followed by rapid diversification. Fast and ancient radiations are respectively associated with short spans of time to accumulate good phylogenetic information in the molecules and long periods to overwrite it with later changes. Both of these phenomena make it difficult to obtain good support for this part of the history of the group. Nonetheless, the presence of three morphological synapomorphies for the terrestrial planarians (cf. Sluys et al., 2009) further supports their unique origin. However, Álvarez-Presas and collaborators (2008) unexpectedly found that three species of freshwater planarians, belonging to the genera Romankenkius and Spathula(Dugesiidae), are situated within the clade of terrestrial planarians, implying a return to a freshwater environment from land and, from a systematic point of view, polyphyly of the Dugesiidae and paraphyly of the Geoplanidae. A more detailed morphological analysis and new molecular data are needed to test this hypothesis. Until then, this new situation has not been reflected in the new Tricladida classification, and the current family Dugesiidae includes all of the freshwater planarians from the superfamily Geoplanoidea. The family Geoplanidae is thus composed of only terrestrial species.

\section{Family Geoplanidae}

The Geoplanidae is divided into four subfamilies (Bipaliinae, Microplaninae, Rhynchodeminae, Geoplaninae) including over 800 described species, although this number is increasing due to extensive sampling and multiple studies being performed both in South America and in Europe. They have a cosmopolitan distribution (Winsor et al., 1998), but most of the species are found in the southern hemisphere, while the Microplaninae are the subfamily with the most northerly distribution (including Africa and Europe).

There are no studies on the relationships among the subfamilies from a morphological point of view, although some hypotheses on the ancestry of certain groups have been posed. Based on their worldwide distribution, Winsor and collaborators (1998) proposed that the rhynchodemids are the earliest divergent terricolans, while Marcus and Froehlich (cf. Sluys 1989b), using characteristics of the copulatory organ, suggested that the Microplaninae are the earliest divergent terricolan clade. The only molecular study (ÁlvarezPresas et al., 2008) gave strong support to a basal position for the family Bipaliidae - never proposed on morphological grounds-and also revealed major problems with the classical taxonomy of the group. The Rhynchodeminae and the Microplaninae (constituting the Family Rhynchodemidae) did not group together; instead, the Rhynchodeminae showed a close relationship to the Caenoplaninae (with the Geoplaninae constituting family Geoplanidae), a situation that has been amended in the new taxonomy (Sluys et al., 2009). Fig. 4 shows the summary tree of those analyses.

Interest in the terrestrial planarians has increased recently as a result of the introduction of non-native predatory species in regions where they have achieved pest status. For example, the New Zealand flatworm, Arthurdendyus triangulatus, has invaded the British Isles and continental Europe (Jones, Boag 1996), and other species have been introduced in North America (Dindal 1970). Land planarians have also been used effectively in Hawaii, the Maldives, Indonesia's Irian Jaya, and Guam to biologically control the introduced giant African snail species Achatina fulica. Some concern exists, however, that the introduction of these predatory land planarians has resulted in the extinction of some native land snails (Sugiura, Yamamura 2006). In addition, due to their fragility with respect to environmental changes and their predator status, terrestrial planarians have been proposed as excellent invertebrate bioindicators for biodiversity and conservation studies (Sluys 1999; Carbayo et al., 2002) and have been demonstrated to be good models in comparative phylogeography studies over small scales in Australia (Sunnucks et al., 2006) and the Brazilian Atlantic Forest (Álvarez-Presas et al., 2011).

\section{Family Dugesiidae}

The family Dugesiidae has received more attention from a systematic point of view. This is probably because its members are among the most easily and frequently found planarians in Europe and North America (genera Dugesia, Schmidtea and Girardia); hence, taxonomists from these continents have dedicated many works to their species. However, the Dugesiidae include many more genera. Ball established the family in 1974 and included 11 genera: Bopsula, Cura, Dugesia, Eviella, Girardia, Neppia, Reynoldsonia, Rhodax, Romankenkius, Schmidtea, Spathula(Ball 1974, 1977). Later, Rhodax was moved to the new taxon Cavernicola (Sluys 1990), and more recently, a new genus, Weissius, has been added to the family (Sluys et al., 2007). Ongoing morphological and molecular studies, both in the Mediterranean and in Australia, show that there is yet a broader diversity within this family and that more genera will likely be described in the future.

The family has a worldwide distribution and 3 of the 11 genera are present in the northern hemisphere: Girardia, Dugesia and Schmidtea. The two last genera mentioned originated on Laurasia: 
Dugesia is distributed across Europe, Asia and Africa, whereas Schmidtea has a nearly exclusive European distribution (some populations have been described from North Africa). Girardia originally had an American distribution, although one species (Girardia tigrina) was introduced to Europe at the beginning of the 20th century. Similarly, Schmidtea polychroa was introduced in America.

The phylogenetic relationships within the family were first examined by Ball (1974), based on various morphological characters, thus producing a very preliminary scheme. It was 30 years before the first phylogeny was produced based on a species-level analysis of a large number of morphological features (Sluys 2001). That study was unable to find unambiguous derived features for some major clades, resulting in some polytomies. However, the analysis supported some conclusions, such as the basal situation of Spathula (which included the genera Reynoldsonia and Eviella, probably merely being aberrant species of Spathula). Romankenkius and Neppia constituted a monophyletic group sister to a clade that includes Girardia, Schmidtea, Cura and Dugesia (the last one being the first offshoot of the group). This is in contrast with a recent molecular study of the Continenticola (Álvarez-Presas et al., 2008), in which the genera Spathula and Romankenkius were not grouped within the Dugesiidae but within the Geoplanidae (Eviella, Weissius and Reynoldsonia were not included in the analysis). Within the monophyletic Dugesiidae, Girardia was most basal, and Dugesia and Schmidtea constituted a sister clade to Cura (Fig. 4).

\section{Schmidtea (Ball 1974)}

The genus Schmidtea was originally known as the Dugesia lugubris-polychroa group or Dugesia lugubris s.I. (Benazzi 1957; Reynoldson, Bellamy 1970) and later as the subgenus Dugesia (Schmidtea) (Ball, 1974). Finally, it was raised to the genus level, together with the other two subgenera of Dugesia (Dugesia (Dugesia) and Dugesia (Girardia)); De Vries, Sluys 1991), based on morphological differences. Later, molecular data supported this new taxonomical status (Riutort et al., 1992). Seven biotypes (named with letters $A, B, C, D, E, F$ and $G$ ) were recognized within the genus, differing in their karyotype (chromosome morphology) and ploidy level (cf. Benazzi, Benazzi-Lentati, 1976). Benazzi recognised the existence of 3 species: D. polychroa (including biotypes $A, B, C$ and D), D. lugubris (E,F) and D. mediterranea (biotype G) (Benazzi et al., 1975). Later, the new species $D$. nova was described for biotype $F$ (Benazzi 1982). Within each species, either amphimictic (diploids) or parthenogenetic (polyploids) modes of reproduction can be found. S. mediterranea presents a third type of reproduction, fissiparity, in diploid populations presenting a heteromorphic translocation. This type of reproduction is common in other genera of planarians, such as Dugesia; however, this is the only known case in Schmidtea. While there is no specific study analysing the relationships among the Schmidtea species, they have been included in some molecular studies. Such analyses have shown a closer relationship between $S$. polychroa and $S$. mediterranea, whereas the relationship between $S$. lugubris and $S$. nova is not clear due to the lack of good molecular information for the latter (Álvarez-Presas et al., 2008; Lazaro et al., 2011). It is worth noting that the molecular analyses revealed a low level of diversification of the group as compared to other Dugesiidae genera of similar age, particularly Dugesia. It is possible that these four species have a recent origin, but molecular trees seem to show an old diversification, which could give support to the idea that they are the remnants of a more widespread diversity (Lazaro et al., 2011).

\section{Dugesia (Girard, 1850)}

Dugesiais a species-rich genus, in stark contrast with Schmidtea. It includes approximately 75 described species with a wide distribution, viz. the Afrotropical, Palearctic, Oriental, and Australian biogeographic regions. Of these 75 species, more than 20 occur in Europe and in the Mediterranean area (cf. Sluys et al., 1998), indicating a wide radiation of the genus in this area. However, several factors render the number and distribution of Dugesia species in the Mediterranean uncertain. First, they are externally very similar. Second, many of their populations are triploid and reproduce asexually by fission (fissiparous forms). Such forms do not develop a reproductive system or copulatory apparatus, the only source of diagnostic taxonomic characters, thus making proper species assignment impossible. The net result for Dugesia in the Mediterranean is the presence of several sexually reproducing species occurring together with a much larger number of asexual triploid populations that have been known as Dugesia gonocephala s.l. or, in more recent studies, as Dugesia sp. The broadest phylogenetic study based on morphological data to date (Sluys et al., 1998) found two monophyletic clades, defined by the course of the ejaculatory duct. Unfortunately, the number of characters was insufficient to obtain a fully resolved phylogeny for the whole genus, thus resulting in a highly polytomous phylogenetic tree.

The use of molecular data for species identification in asexual populations and to resolve phylogenies for species in the western Mediterranean has been a successful strategy (Baguñà et al., 1999; Lazaro et al., 2009). These studies have demonstrated that the mitochondrial gene Cytochrome Oxidase I (COI) is an excellent barcoding tool that allows the assignment of the asexual populations to species and at the same time, together with the nuclear marker ITS-1, has resulted in a well-resolved phylogeny. The results of these studies yielded many interesting points:

1. Dugesia is divided in two main molecular groups in the western Mediterranean. There are some differences with the groups defined on morphological grounds. One of the groups includes only two species ( $D$. sicula and $D$. aethiopica) at present, and all the rest belong to a clade that we will here call the European clade.

2. Most of the triploid asexual populations found in the Mediterranean basin belong to the species $D$. sicula. Although other species have asexual populations, in general, they have an endemic distribution, and only a few populations show that type of reproduction.

3. The sicula-aethiopicaclade presents two outstanding features: almost molecular identity between the two species and low genetic diversity among $D$. sicula populations geographically distant as Greece, Italy, Tunisia, Spain and the Canary Islands.

4. D. gonocephala, the North European representative of the genus, presents low genetic diversity, is buried deeply within the tree and is closely related to some Italian species, suggesting that European colonisation proceeded from South to North.

5. All central European D. gonocephala populations studied are grouped into clades, with nearly no genetic diversity within them and with low diversity among them. Nonetheless, they are older than the last glacial maximum, suggesting the presence of various glacial refugia in Central Europe from which the species spread after the Ice Age.

6. D. subtentaculata, the only species of the European clade known to be present in the Iberian Peninsula, shows a high genetic 
differentiation between the only two sexual populations studied molecularly thus far (both in Mallorca). This differentiation is even stronger when compared to the asexual populations analysed. This suggests a highly structured species or even the existence of more than one species. $D$. subtentaculata has in common with $D$. sicula the fact that most of its populations are asexual but is different in that geographically close populations are highly differentiated. However, a more detailed molecular analysis of the populations present in Spain may reveal the existence of more than one species and change this impression.

7. The rest of the species of the group are primarily endemic to in small continental areas or islands. In Greece, from where 9 endemic species have been described (De Vries 1984), studies in progress (Solà et al., in preparation) indicate that molecular clades coincide with morphologically described species, or else molecular and morphological data point to the existence of new species (Sluys et al., in preparation). Also, the relationships found among the species mostly correlate with the complex geological history of the region, which will allow the calibration of a molecular clock.

\section{Perspectives}

In the genomic era, the ease of acquiring massive amounts of molecular data, even from single individuals, is beginning to open new possibilities for systematic studies. In Platyhelminthes in general and planarians in particular, the new era could mean, on the one hand, finally solving the unsettled position of the phylum within the Metazoa. On the other hand, it will make possible the extraction of genetic data at the population level and, hence, allow their use in fine-scale phylogeographical and demographic studies. This will give planarians a role that was previously closed to non-model organisms, enabling their use in studies on the origin and maintenance of biodiversity and its conservation.

\section{Acknowledgements}

We would like to acknowledge all people who provided material and data that made possible the work described in this review. We also will like to thank all the collaborators in the different projects that are reviewed here, specially Tim Littlewood, Ronald Sluys, Maria Pala, Giacinta Stocchino, Saïda Tekaya, Abdul Halim Harrath, Fernando Carbayo. We are grateful to the past PhD students of the Molecular phylogeny group, Salvador Carranza and Iñaki Ruiz-Trillo, now with a successful career of their own, for having contributed to the advance of the studies here presented. Special thanks are due to Jaume Baguñà, who initiated this line of research at the end of the 80s when he introduced MR into the world of phylogenetics. None of this would have been possible without his perseverance in arising interesting questions on the evolution of animals, and in trying to find the best and most innovative ways to answer them. This work was funded by grants from the Ministerio de Educación y Ciencia PB90-0477, PB97-0937, BOS2002-02097 to Jaume Baguñà and CGL2005-00371/BOS, CGL2008-00378/BOS to MR, and from the Generalitat de Catalunya Nos. 1999SGR-00026 and 2001SGR-00102 to Jaume Baguñà.

\section{References}

ABOUHEIF, E., ZARDOYA, R. and MEYER, A. (1998). Limitations of metazoan $18 S$ rRNA sequence data: implications for reconstructing a phylogeny of the animal kingdom and inferring the reality of the Cambrian explosion. JMolEvo/47:394-405.

ÁLVAREZ-PRESAS, M., BAGUÑÀ, J. and RIUTORT, M. (2008). Molecular phylogeny of land and freshwater planarians (Tricladida, Platyhelminthes): From freshwater to land and back. Mol Phylogenet Evol 47: 555-568.
ÁLVAREZ-PRESAS, M., CARBAYO, F., ROZAS, J. and RIUTORT, M. (2011). Land planarians (Platyhelminthes) as a model organism for fine-scale phylogeographic studies: understanding patterns of biodiversity in the Brazilian Atlantic Forest hotspot. J Evolution Biol 24: 887-896.

ANDERSON, F.E., CORDOBA, A.J. and THOLLESSON, M. (2004). Bilaterian phylogeny based on analyses of a region of the sodium-potassium ATPase beta-subunit gene. J Mol Evol 58: 252-68.

BAGUÑÀ, J., CARRANZA, S., PALA, M., RIBERA, C., GIRIBET, G., ARNEDO, M.A., RIBAS, M. and RIUTORT, M. (1999). From morphology and karyology to molecules. New methods for taxonomical identification of asexual populations of freshwater planarians. A tribute to Professor Mario Benazzi. Ital. J. Zool. 66: 207-214.

BAGUÑÀ, J., CARRANZA, S., PAPS, J., RUIZ-TRILLO, I. and RIUTORT, M. (2001). Molecular taxonomy and phylogeny of Tricladida. In Interrelationships of the Platyhelminthes (Eds. D.T.J. Littlewood and R.D. Bray). Taylor and Francis, London, England, pp: 49-56.

BAGUÑÀ, J. and RIUTORT, M. (2004). Molecular phylogeny of the Platyhelminthes. Can. J. Zool, no. 82: 168-193.

BALL, I.R. (1981). The phyletic status of the Paludicola. Hydrobiologia 84: 7-12.

BALL, I.R. (1977). On the phylogenetic classiccation of aquatic planarians. Acta Zool. Fenn. 154: 21-35.

BALL, I.R. (1974). A contribution to the phylogeny and biogeography of the freshwater Triclads (Platyhelminthes: Turbellaria). Biology of the Turbellaria, (Eds. N.W. Riser and M.P. Morse). McGraw-Hill, NY.

BENAZZI, M. (1982). Speciation events evidenced in Turbellaria. In Mechanisms of Speciation (Ed. C. Barigozzi, Alan R. Liss). New York, pp. 307-344.

BENAZZI, M. (1957). Cariologia di Dugesia lugubris (0. Schmidt) (Tricladida, Paludicola). Cariologia 10: 276-303.

BENAZZI, M., BAGUÑ̇̀, J., BALLESTER, R., PUCCINELLI, I. and DEL PAPA, R (1975). Further contribution to the taxonomy of the Dugesia lugubris-polychroa group- with description of Dugesia mediterranea n.sp. (Tricladida, Paludicola). Boll. Zool. 42: 81-89.

BENAZZI, M. and BENAZZI-LENTATI, G. (1976). Animal Cytogenetics. Vol. I Platyhehninthes, Gebruder Borntraeger, Berlin.

BOURLAT, S.J., NIELSEN, C., ECONOMOU, A.D. and TELFORD, M.J. (2008). Testing the new animal phylogeny: A phylum level molecular analysis of the animal kingdom. Mol Phylogenet Evol 49: 23-31.

CARBAYO, F., LEAL-ZANCHET, A.M. and VIEIRA, E.M. (2002). Terrestrial flatworm (Platyhelminthes: Tricladida: Terricola) diversity versus man-induced disturbance in an ombrophilous forest in southern Brazil. Biodiversity and Conservation 11: 1091-1104.

CARRANZA, S., BAGUÑÀ, J. and RIUTORT, M. (1997). Are the Platyhelminthes a monophyletic primitive group? An assessment using $18 \mathrm{~S}$ rDNA sequences. Mol Biol Evol 14: 485-497.

CARRANZA, S., LITTLEWOOD, D.T.J., CLOUGH, K.A., RUIZ-TRILLO, I., BAGUÑÀ, J. and RIUTORT, M. (1998). A robust molecular phylogeny of the Tricladida (Platyhelminthes: Seriata) with a discussion on morphological synapomorphies P Roy Soc B-Biol Sci 265: 631-640.

CARRANZA, S., BAGUÑÀ, J. and RIUTORT, M. (1999). Origin and Evolution of Paralogous rRNA Gene Clusters Within the Flatworm Family Dugesiidae (Platyhelminthes, Tricladida). $J$ Mol Evol. 49: 250-259.

CAVALIER-SMITH, T. (1998). A revised six-kingdom system of life. Biol Rev 73: 203.

CHARBAGI-BARBIROU, K., ÁlVAREZ-PRESAS, M., VILA, M., GAMMOUDI, M., TEKAYA, S. and RIUTORT, M. (2011). Marine triclads (Platyhelminthes, Tricladida, Maricola). a preliminary molecular approach to their phylogeny. Cah. Biol. Mar. 52: 303-311.

DE BEAUCHAMP, P. (1961). Classe des Turbellariés. In Traité de Zoologie (Ed. P. Grassé), Masson et Cie, Paris. pp. 35-212.

DE VRIES, E.J. (1984). On the species of the Dugesiagonocephalagroup (Platyhelminthes, Turbellaria, Tricladida) from Greece. Bijdragen tot de Dierkunde 54:101-126.

DE VRIES, E.J. and SLUYS, R. (1991). Phylogenetic relationships of the genus Dugesia (Platyhelminthes, Tricladida, Paludicola). J Zool (Lond) 223: 103-116.

DIESING, K.M. (1850). Systema Helminthum, Vindobonae.

DINDAL, D.L. (1970). Feeding behaivor of a terrestrial turbellarian Bipalium adventitium. Am. Midl. Nat. 83: 635-637.

DUNN, C.W., HEJNOL, A., MATUS, D.Q., PANG, K., BROWNE, W.E., SMITH, S.A., 
SEAVER, E., ROUSE, G.W., OBST, M., EDGECOMBE, G.D., SORENSEN, M.V., HADDOCK, S.H.D., SCHMIDT-RHAESA, A., OKUSU, A., KRISTENSEN, R.M., WHEELER, W.C., MARTINDALE, M.Q. and GIRIBET, G. (2008). Broad phylogenomic sampling improves resolution of the animal tree of life. Nature 452: 745-749.

EHLERS, U. (1985). Das Phylogenetische System der Plathelminthes. G. Fischer. Stuttgart and New York.

EHRENBERG, C.G. (1831). Animalia evertebrata exdusis Insectis in Symbolae physicae (Ed. Fredericus Guilelmus Hemprich and Christianus Godofredus Ehrenberg). Symbolae physicae. Volume 4, series prima cum tabularum decade prima. Berolini.

FALLENI, A., LUCCHESI, P., GHEZZANI, C., MCDONALD, J.C. and JONES, H.D. (2009). The female gonad in two species of Microplana (Platyhelminthes, Tricladida, Rhynchodemidae): Ultrastructural and cytochemical investigations. $J$ Morphol. 270: 1042-1054.

FIELD, K.G., OLSEN, G.J., LANE, D.J., GIOVANNONI, S.J., GHISELIN, M.T., RAFF, E.C., PACE, N.R. and RAFF, R.A. (1988) Molecular phylogeny of the animal kingdom. Science 239: 748-753.

GAREY, J.R. (2002). The Lesser-Known Protostome Taxa: An Introduction and a Tribute to Robert P. Higgins. Int. Comp. Biol. 42: 611-618.

GEGENBAUR, C. (1859). Grundzuge der vergleichenden Anatomie. W. Engelmann, Leipzig, Germany.

GEGENBAUR, C., JEFFREY BELL, F. and RAY LANKESTER, E. (1878). Elements of Comparative Anatomy, MacMillan and Co, London.

GIRIBET, G., DISTEL, D.L., POLZ, M., STERRER, W. and WHEELER, W.C. (2000), Triploblastic relationships with emphasis on the acoelomates and the position of Gnathostomulida, Cycliophora, Plathelminthes, and Chaetognatha: a combined approach of 18S rDNA sequences and morphology. Syst Biol 49: 539-62.

GRAFF, L.V. (1882). Monographie der Turbellarien. I. Rhabdocoela.

HAECKEL, E. (1866). Generelle Morphologie der Organismen. Allgemeine Grundzüge der organischen Formen-Wissenschaft, mecanisch begründet durch die von Charles Darwin reformirte Descendenz-Theorie. 2 vols. Verlag von Georg Reimer, Berlin.

HAECKEL, E. (1876). The History of Creation (6th New English Edition 1914). D. Appelton and Company, New York.

HALANYCH, K.M. (2004). The new view of animal phylogeny. Annual Review of Ecology, Evolution, and Systematics 35: 229-256.

HALLEZ, P. (1894). Catalogue des Rhabdocoelides, Triclades and Polyclades du Nord de la France. 2nd ed. edn, L. Daniel, Lille (France).

HASZPRUNAR, G. (1996a). The Mollusca: coelomate turbellarians or mesenchymate annelids? In Origin an Evolutionary Radiation of the Mollusca. (Ed. J. Taylor, Oxford University Press, Oxford, pp. 1-28.

HASZPRUNAR, G. (1996b). Plathelminthes and Plathelminthomorpha - paraphyletic taxa. J Zool Syst Evol Res 34: 41-48.

HEJNOL, A., OBST, M., STAMATAKIS, A., OTT, M., ROUSE, G.W., EDGECOMBE, G.D., MARTINEZ, P., BAGUÑÀ, J., BAILLY, X., JONDELIUS, U., WIENS, M., MÜLLER, W.E.G., SEAVER, E., WHEELER, W.C., MARTINDALE, M.Q., GIRIBET, G. and DUNN, C.W. (2009). Assessing the root of bilaterian animals with scalable phylogenomic methods. P Roy Soc B-Biol Sci 276: 4261-4270.

HYMAN, L.H. (1951). The Invertebrates: Platyhelminthes and Rhynchocoela the acoelomate Bilateria, McGraw-Hill, London and New York.

HYMAN, L.H. (1940). The invertebrates: Protozoathrough Ctenophora. Vol 1. New York.

HYMAN, L.H. (1937). Studies on the morphology, Taxonomy, and distribution of North American Triclad Turbellaria. VIII. Some cave Planarians of the United States. Transactions of the American Microscopical Society 56: 457-477.

JONDELIUS, U., RUIZ-TRILLO, I., BAGUÑÀ, J. and RIUTORT, M. (2002). The Nemertodermatida are basal bilaterians and not members of the Platyhelminthes. Zool Scr 31: 201-215.

JONES, H.D. and BOAG, B. (1996). The distribution of New Zealand and Australian terrestrial flatworms (Platyhelminthes: Turbellaria: Tricladida:Terricola) in the British Isles-the Scotish survey and Megalab worms. J. Nat. Hist. 30: 955-975.

KARLING, T.G. (1974). On the anatomy and affinities of the Turbellarian orders. In Biology of the Tureballaria. McGraw-Hill., NewYork: 1-16.

KENK, R. (1975). Fresh-water triclads (Turbellaria) of North America. VII. The genus Macrocotyla. Trans Am Microsc Soc 94: 324-339.

KENK, R. (1974). Index of the genera and species of the freshwater Triclads (Turbellaria) of the World. Smithsonian Contrib. Zool. 183: 1-90.
KENK, R. (1930). Beiträge zum System der Probursalier (Tricladida Paludicola). III. Zool. Anz. 89: 289-302.

LAZARO, E.M., SLUYS, R., PALA, M., STOCCHINO, G.A., BAGUÑÀ, J. and RIUTORT, M. (2009). Molecular barcoding and phylogeography of sexual and asexual freshwater planarians of the genus Dugesiain the Western Mediterranean (Platyhelminthes, Tricladida, Dugesiidae). Mol Phylogenet Evol 52: 835-845.

LAZARO, E., HARRATH, A.H., STOCCHINO, G., PALA, M., BAGUNA, J. and RIUTORT, M. (2011). Schmidtea mediterranea phylogeography: an old species surviving on a few Mediterranean islands? BMC Evol Biol 11: 274

LITTLEWOOD, D.T.J. and OLSON, P.D. (2001). Small subunit rDNA and the Platyhelminthes: signal, noise and compromise. In The interrelationships of the Platyhelminthes (Ed. D.T.J.a.B. Littlewood R.D.) Taylor and Francis, London, England. pp: 262-278.

LITTLEWOOD, D.T.J., ROHDE, K., BRAY, R.A. and HERNIOU, E.A. (1999a). Phylogeny of the Platyhelminthes and the evolution of parasitism. Biol J Linn Soc 68 1-2: 257-287.

LITTLEWOOD, D.T.J., ROHDE, K. and CLOUGH, K.A. (1999b). The interrelationships of all major groups of Platyhelminthes: phylogenetic evidence from morphology and molecules. Biol J Linn Soc 66: 75-114.

MALLATT, J. and WINCHELL, C.J. (2002). Testing the new animal phylogeny: first use of combined large-subunit and small-subunit rRNAgene sequences to classify the protostomes. Mol Biol Evol 19: 289-301.

MALLATT, J., CRAIG, C.W. and YODER, M.J. (2010) Nearly complete rRNA genes assembled from across the metazoan animals: Effects of more taxa, a structurebased alignment, and paired-sites evolutionary models on phylogeny reconstruction. Mol Phylogenet Evol 55: 1-17.

MEDINA, M., COLLINS, A.G., SILBERMAN, J.D. and SOGIN, M.L. (2001). Evaluating hypotheses of basal animal phylogeny using complete sequences of large and small subunit rRNA. P Natl Acad Sci USA. 98: 9707-12.

MITCHELL, R.W. (1968). New species of Sphalloplana (Turbellaria; Paludicola) from the caves of Texas and a reexamination of the genus Speophila and the family Kenkiidae. Ann. Spéléol. 23: 597-620.

MÜLLER, O.F. (1776). Zoologiae danicae prodromus, seu Animalium Daniae et Norvegiae indigenarum characteres, nomina, et synonyma imprimis popularium, Havniae.

NIELSEN, C. (2010). After all: Xenoturbella is an acoelomorph!. Evol Dev12:241-243.

NOREN, M. and JONDELIUS, U. (2002). The phylogenetic position of the Prolecithophora (Rhabditophora,?Platyhelminthes?). Zool Scr 31: 403-414.

PAPS, J., BAGUÑ̇̀, J. and RIUTORT, M. (2009a). Bilaterian Phylogeny: A Broad Sampling of 13 Nuclear Genes Provides a New Lophotrochozoa Phylogeny and Supports a Paraphyletic Basal Acoelomorpha. Mol Biol Evol 26: 2397-2406.

PAPS, J., BAGUÑÀ, J. and RIUTORT, M. (2009b). Lophotrochozoa internal phylogeny: new insights from an up-to-date analysis of nuclear ribosomal genes. $P$ Roy Soc B-Biol Sci 276: 1245-1254.

PHILIPPE, H., BRINKMANN, H., COPLEY, R.R., MOROZ, L.L., NAKANO, H. POUSTKA, A.J., WALLBERG, A., PETERSON, K.J. and TELFORD, M.J. (2011). Acoelomorph flatworms are deuterostomes related to Xenoturbella. Nature 470 : 255-258.

REYNOLDSON, T.B. and BELLAMY, L.S. (1970). The status of Dugesia lugubris and D. polychroa (Turbellaria, Tricladida) in Britain. J Zool Lond. 162: 157-177.

RIUTORT, M., FIELD, K.G., TURBEVILLE, J.M., RAFF, R.R. and BAGUÑÀ, J. (1992) Enzyme electrophoresis, 18S rRNA sequences, and levels of phylogenetic resolution among several species of freshwater planarians (Platyhelminthes, Tricladida, Paludicola). Can. J. Zool 70: 1425-1439.

ROHDE, K. (1990) Phylogeny of platyhelminthes, with special reference to parasitic groups. Int J Parasito. I 20: 979-1007.

RUIZ-TRILLO, I., PAPS, J., LOUKOTA, M., RIBERA, C., JONDELIUS, U., BAGUÑÀ, J. and RIUTORT, M. (2002). A phylogenetic analysis of myosin heavy chain type I sequences corroborates that Acoela and Nemertodermatida are basal bilaterians. P Natl Acad Sci USA. 99: 11246-51.

RUIZ-TRILLO, I., RIUTORT, M., LITTLEWOOD, D.T.J., HERNIOU, E.A. and BAGUÑÀ, J. (1999). Acoel flatworms: earliest extant bilaterian Metazoans, not members of Platyhelminthes. Science 283: 1919-23.

RUPPERT, E.E., FOX, R. and BARNES, R.D. (2003). Invertebrate Zoology: A Functional Evolutionary Approach. Seventh Edition, Brooks/Cole Thompson Learning, Belmont, California. 
SLUYS, R. (2001). Towards a phylogenetic classification and characterization of dugesiid genera (Platyhelminthes, Tricladida, Dugesiidae): a morphological perspective. In The interrelationships of the Platyhelminthes (Ed. D.T.J.a.B. Littlewood R.D.) Taylor and Francis, London, England. pp: 57-73.

SLUYS, R. (1999). Global diversity of land planarians (Platyhelminthes, Tricladida, Terricola): a new indicator-taxon in Biodivers Conserv studies. Biodivers Conserv 8: 1663-1681.

SLUYS, R. (1990). A monograph of the Dimarcusidae (Platyhelminthes, Seriata, Tricladida). Zool Scr 19: 13-29.

SLUYS, R. (1989a). A monograph of the marine triclads. A. A. Balkema, Rotterdam.

SLUYS, R. (1989b). Phylogenetic relationships of the triclads (Platyhelminthes, Seriata, Tricladida). Bijdr. Dierkd. 59: 3-25.

SLUYS, R., GRANT, L. and BLAIR, D. (2007). Freshwater planarians from artesian springs in Queensland, Australia (Platyhelminthes, Tricladida, Paludicola). Contrib Zool 76: 9-19.

SLUYS, R. and KAWAKATSU, M. (2006). Towards a phylogenetic classification of dendrocoelid freshwater planarians (Platyhelminthes): a morphological and eclectic approach.. 44: 274-284.

SLUYS, R., KAWAKATSU, M., RIUTORT, M. and BAGUÑÀ, J. (2009) A new higher classification of planarian flatworms (Platyhelminthes, Tricladida). J Nat Hist 43 29-30: 1763-1777.

SLUYS, R., KAWAKATSU, M. and WINSOR, L. (1998). The genus Dugesia in Australia, with its phylogenetic analysis and historical biogeography (Platyhelminthes, Tricladida, Dugesiidae). Zool Scr 27: 273-290.

SMITH J.P.S., TYLER S., RIEGER R.M. (1986). Is the Turbellaria polyphyletic?.
Hydrobiologia 132: 13-21.

SOPOTT-EHLERS, B. (1985). The phylogenetic relationships within the Seriata (Platyhelminthes). In The origins and relationships of lower invertebrates. (Eds. S. Conway-Morris, J.D. George, R. Gibson and H.M. Platt) Clarendon Press, Oxford: $159-167$

SPERLING, E.A., PETERSON, K.J. and PISANI, D. (2009). Phylogenetic-Signal Dissection of Nuclear Housekeeping Genes Supports the Paraphyly of Sponges and the Monophyly of Eumetazoa. Mol Biol Evol 26: 2261-2274.

STEINBÖCK, O. (1925). Zur Systematik der Turbellaria metamerata, zugleich ein Beitrag zur Morphologie des Tricladen-Nervensystems. Zool. Anz. 64: 165-192.

SUGIURA, S. and YAMAMURA, Y. (2009). Potential impacts of the invasive flatworm Platydemus manokwari on arboreal snails. Biol.Invasions 11: 737-742.

SUNNUCKS, P., BLACKET, M.J., TAYLOR, J.M., SANDS, C.J., CIAVAGLIA, S.A., GARRICK, R.C., TAIT, N.N., ROWELL, D.M. and PAVLOVA, A. (2006). A tale of two flatties: different responses of two terrestrial flatworms to past environmental climatic fluctuations at Tallaganda in montane southeastern Australia. 15: 4513-4531.

TELFORD, M.J., LOCKYER, A.E., CARTWRIGHT-FINCH, C. and LITTLEWOOD, D.T.J. (2003). Combined large and small subunit ribosomal RNA phylogenies support a basal position of the acoelomorph flatworms. P Roy Soc B-Biol Sci 270: 1077-83.

TURBEVILLE, J.M. (2002). Progress in Nemertean Biology: Development and Phylogeny. Integrative and Comparative Biology 42: 692-703.

VALENTINE, J.W. (2004). On the Origin of Phyla. University Of Chicago Press.

WINSOR, L., JOHNS, P.M. and YEATES, G.W. (1998). Introduction, and ecological and systematic background, to the Terricola (Tricladida). Pedobiologia42:389-404. 


\section{Further Related Reading, published previously in the Int. J. Dev. Biol.}

Segmentation, metamerism and the Cambrian explosion Juan Pablo Couso

Int. J. Dev. Biol. (2009) 53: 1305-1316

The sudden appearance of diverse animal body plans during the Cambrian explosion Jun-Yuan Chen

Int. J. Dev. Biol. (2009) 53: 733-751

From Planarians to Mammals - the many faces of regeneration

Jerzy Moraczewski, Karolina Archacka, Edyta Brzoska, Maria-Anna Ciemerych, Iwona Grabowska, Katarzyna Janczyk-Ilach, Wladyslawa Streminska and Malgorzata Zimowska Int. J. Dev. Biol. (2008) 52: 219-227

Hox and ParaHox genes in Nemertodermatida, a basal bilaterian clade Eva Jiménez-Guri, Jordi Paps, Jordi García-Fernández and Emili Saló Int. J. Dev. Biol. (2006) 50: 675-679

The place of phylogeny and cladistics in Evo-Devo research Maximilian J Telford and Graham E Budd

Int. J. Dev. Biol. (2003) 47: 479-490

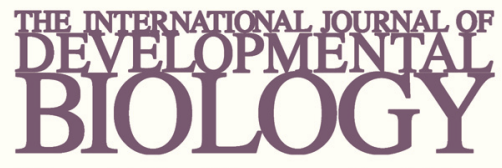

Volume 54 Nos. 6/7

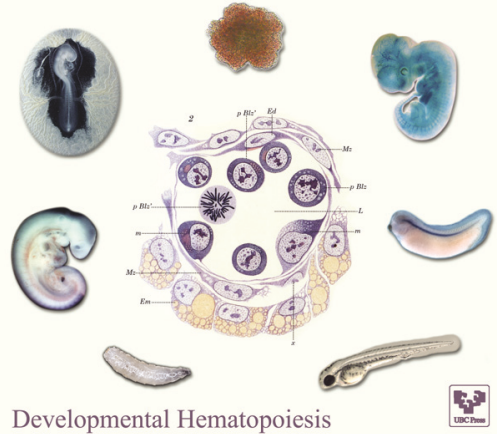

5 yr ISI Impact Factor $(2010)=2.961$

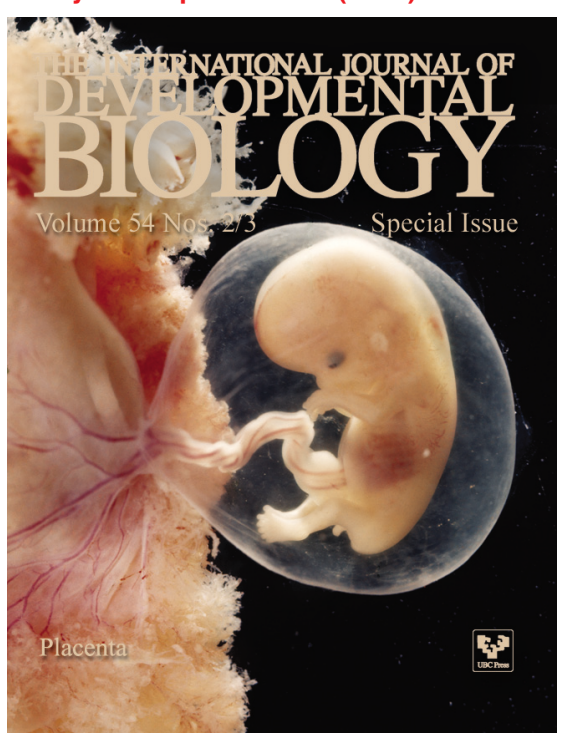

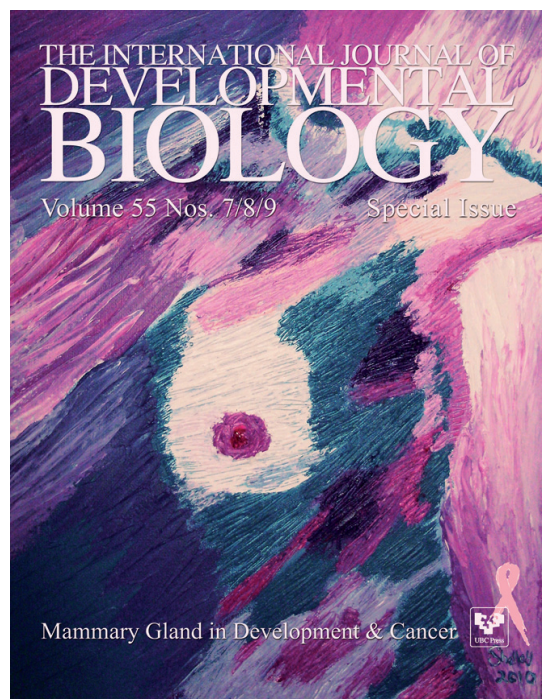

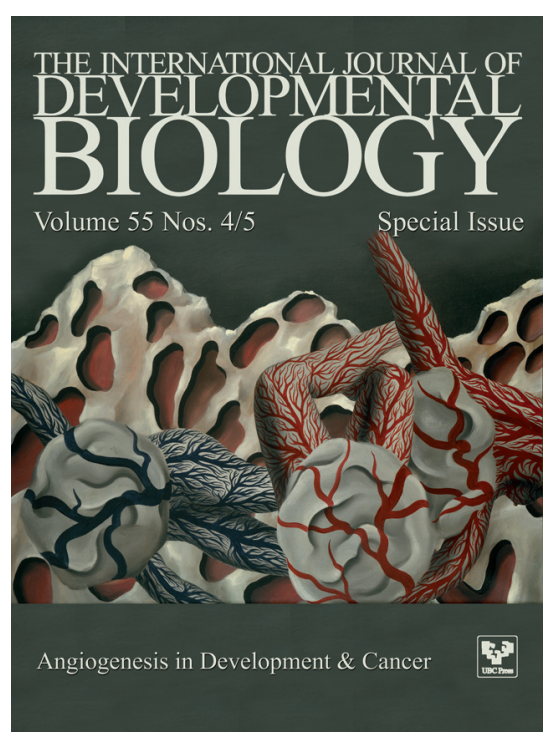

